


\title{
Jubilæumsanmeldelse
}

\section{Torben Brostrøms Versets Løvemanke}

\author{
Af Erik Skyum-Nielsen
}

Skønt Torben Brostrøms første egentlige bog snart blev fulgt op af hans Poetisk Kermesse (1962), Ti års lyrik (1966) og Labyrint og arabesk (1967), og på trods af, at han selv ret hurtigt fik følgeskab af fagligt beslægtede litteraturpædagoger og lyrikentusiaster, står Versets Løvemanke fra 1960 stadigvæk som en milepæl i moderne dansk litteraturforskning og litteraturkritik. Her forsøgtes nemlig, i selve gennembrudsåret for 60'ernes lyriske modernisme, en pejling af, hvad der var i færd med at ske, og en præsentation af de på det tidspunkt vigtigste poetiske aktører.

Bogens kerne udgøres af syv forfatterskabsgennemgange fulgt op af en sammenfatning, der til sidst tager fat på de to i tiden ømtålelige spørgsmål om modernismens forhold til romantikken og til senfyrrernes poesi, idet det stilfærdigt konkluderes, at det nye muligvis »ligger i en større dristighed og selvstændighed i opfattelsen af det poetiske « (143) og i en blanding af symbolistisk romantik og saglighed. Polemikken imod Heretica-lyrikken er her tydeligvis stemt en tone ned i forhold til den programartikel om »Det umådelige mådehold « i tidsskriftet Vindrosen, 1959, som for eftertiden desværre har fået lov at indvarsle 60'er-modernismen og tegne Brostrøms position som dennes vigtigste kritiker.

Men i Versets Løvemanke er selve genren netop også en anden. Her skrives ikke kun for øjeblikket, men også for eftertiden, og her benytter forfatteren chancen for som den første herhjemme at introducere nykritikkens principper: At litteratur primært er et medium for erkendelse. At form og indhold i poesi ikke bør, ja, slet ikke kan skilles ad. At digte rummer en helhedsmening af form og indhold, poesiens mening. At digtet skal opfattes som en verden i sig selv, uafhængigt af digterens person og intention (autonomiprincippet). At der må skelnes mellem digtets baggrund og digtets eget rum. Og at det ved beskrivelsen af dette litterære rum drejer sig om at identificere tekstens indre struktur. Fremfor at spørge: hvad vil digteren sige os med det digt, hvad kan vi lære af det? bør vi spørge, hvad digtet selv siger, og først og fremmest lære os at lytte. 
Denne tilgang til læsning af lyrik går i sidste ende tilbage til romantikken og dens revolution af kunstoplevelsen, herhjemme nok mønstergyldigst manifesteret af især Schack Staffeldt: »Når det religiøse toner bort, er poesien da tilbage som livsforklaring, den er blevet redskab til erkendelse, indgivelsen bliver af højere art, det poetiske billede bliver autonomt « (144). For lyrikerne i Brostrøms samtid gælder det, at nye oplevelsesformer afføder nye poetiske former, hvis interesse er den »at fjerne det sløvhedens lag, der hindrer det elementære forhold til virkeligheden« (68), for nu at citere en typisk formulering, brugt om Robert Corydons Sarvig-inspirerede poesi. »I kunsten indhenter vi os selv og den virkelighed, vi lever i«, lyder det overordnede credo (148). At tilegne sig moderne lyrik er for kritiker og læser en enestående mulighed for at udrydde sine vaneforestillinger og tænke utraditionelt.

Problemet er så uheldigvis, at de fleste foretrækker at tænke traditionelt, at nye udtryk og nye følemåder altid »vil virke ekstreme, indtil man har erkendt deres realitet hos sig selv« (140). Den nye poesi afvises som dunkel, vanskelig, uforståelig, underligt tør i formen (14), men denne matte afvisning falder jo blot tilbage på læserne selv: »Den dunkle poesis upopularitet skyldes, at mange læsere ikke vil genkende deres egen virkelighed « (134). Kritikerens opgave bliver da at stille sig utvetydigt på kunstens side og vise, at den nye poesi er krævende uden at være svær, hemmelighedsfuld uden dog at være dyb og dunkel. I denne mission bliver hans middel at foreslå nye adækvate læsemåder, idet han villigt medgiver, at »halvdelen af modtageprocessen er et forstandspræget arbejde« (19). Skønt lyrikkens sprog egentlig ikke er spor dunkelt, så åbner det sig jo ikke sådan lige af sig selv.

For at sætte sig ind i Torben Brostrøms og hans kollegers litteraturpædagogiske udfordring her i årene omkring 1960 er det nok nødvendigt at huske på den folkelige succes, som mange af de sene 40'eres lyrikere stadig nød, og som her i landet nok til dels kan forklare »publikum-forståelsens kritiske situation« (145) i konfrontationerne med den nye, vanskelige digtning. Herom skriver han selv, åbent - og beundringsværdigt frimodigt:

Før i tiden forstod alle kunst, hedder det sig. Det er imidlertid en fiktion. Flere mente at forstå kunst, ligesom de nu mener at forstå den traditionelle kunst. Forholdet er nok det, at det nu viser sig, at ret få forstår kunst overhovedet, og at det, man forstår af den traditionelle er noget andet end kunsten. F.eks. det specielle i digtnin- 
gen, der kan bruges til at samle folk om nationen, Gud, den sunde fornuft, moralen o.s.v.

Højskole- og kirkefolk kunne let i Heretica-generationens frembringelser genkende deres egne problemer, men stod i begyndelsen fremmede for de sene 50'eres fysiologiske og indimellem surrealistisk inspirerede, billedynglende poesi, hvortil så kom, at denne mestendels betjente sig af såkaldte frie, altså ikke-sangbare vers. Men, betoner Brostrøm fornuftigt, de frie vers opgiver jo netop ikke rytmen, »stadigvæk vil man i de allerfleste frie vers finde løsere eller fastere rytmesystemer« (47). Der er blot sket det, at det visuelle har vundet ind på det motorisk-auditive, uden at det har ændret ved, at den sproglige inspiration basalt forbliver musikalsk bestemt (50f).

Præciseringer som denne var nødvendige i datidens litteraturpædagogiske situation, men er karakteristiske for Torben Brostrøms særlige underspillede tilgang. Det principielle udgangspunkt og den litteraturkritiske position delte han med Johan Fjord Jensen (Den nye kritik, 1962), Steffen Hejlskov Larsen (Om at loese moderne poesi, 1962; Lyriske tilvaerelsesmodeller, 1965), Finn Brandt-Petersen (Modernisme og kvalitet, 1965; Modernisme og padagogik, 1966), men hans gennemslagskraft hang paradoksalt nok sammen med hans søgende, spørgende facon. Selv når han som ovenfor antydet kolporterer nykritikkens dogmer om tekstens autonomi, enheden af form og indhold og strukturens forrang i forhold til digtets motiv eller stof, agerer han velgørende udogmatisk. Nok finder man i Versets Løvemanke talrige skarpe spidsformuleringer, men bogens væsentligste kvaliteter er den poetiske lydhørhed, den eminente karakteriseringsevne, sansen for at give digte et sensitivt medløb uden dermed at miste sit eget overordnede mål af syne.

Disse egenskaber ved Torben Brostrøms fremgangsmåde træder særlig tydeligt frem i de syv digterportrætter, som optager halvdelen af bogen. Her lytter han sig, med sikker fornemmelse for nuancerne og de individuelle særpræg, ind på Ivan Malinovski (som senere skrev sig Malinowski, og som debuterede 1945, men siden strøg de to første digtsamlinger af forfatterskabet og derfor regnede Galgenfrist (1958) for sin egentlige debut), Uffe Harder (debut 1954), Robert Corydon (debut 1950), Cecil Bødker (debut 1955), Jørgen Gustava Brandt (debut 1949, på Wivels Forlag, og dermed som Heretica-digter!), Jørgen Sonne (debut 1950) og Klaus Rifbjerg (debut i 1956 med Under vejr med mig selv, som fulgtes af Efterkrig (1957), hvis titeltekst dog går helt tilbage til 1952). 
Kritikeren optræder her, ikke som den herold, der forkynder det nyes triumferende ankomst - tre af digterne havde som anført debuteret 10-11 år før - ej heller som bonden, der pløjer marken igennem inden han sår, for Brostrøms opgave er at modtage, ikke at føde - men snarere som en mosrive, der luger op i de gamle vækster for at skaffe lys og luft til det fremvoksende friske græs. Overalt vil man derfor kunne støde på formuleringer, som formelig strutter af optimisme på poesiens vegne. Om Ivan Malinovski hedder det præcist, at det opgør »med troen på værdierne, med religion og objektiv moral«, som digteren tidligt gjorde sig til talsmand for, måske nok kunne forstås som nihilisme, men i virkeligheden var et udtryk for hans respekt og omsorg for det, der er tilbage, »når mennesket er afklædt alle sine værdigheder« (53f). Om Uffe Harder skriver Brostrøm generelt, at han tror på poesiens skabende, inspirerende kraft $\mathrm{i}$ andre mennesker, og at denne tro går hånd $\mathrm{i}$ hånd med »den anonyme, åndeagtige sensibilitet, der søger sin realitet i et billede« (61). Om Robert Corydon, som arbejder med det »rene« digt og nedfælder skarpt sansede iagttagelser, får vi at vide, at hos ham bliver tingene til tegn. Han søger at ")genoprette vort umiddelbare forhold til naturen ved at gøre sproget effektivt gennem det prægnante billede« (66).

Torben Brostrøm har tydeligvis svært ved at give sig uforbeholdent hen til Cecil Bødkers ærkeromantiske idé, at mennesket har fjernet sig fra naturen, og at digterens grundopgave derfor bliver den »at finde og knytte sig til det elementære « (84), og når han i forbindelse med (især den tidlige) Jørgen Gustava Brandt præcist registrerer efterklangene af Sophus Claussen, Johannes V. Jensen, Tom Kristensen og Thorkild Bjørnvig (94f), hænger det temmelig åbenlyst sammen med et personligt forbehold over for Gustavas tit åbent vedkendte æsteticisme og denne poets måske lidt fade bestræbelse på »i glæde og kærlighed at nå frem til de øjeblikke, hvor tilværelsen opleves hel« (92).

Anderledes forbeholdsfrie forekommer de noget mere omfangsrige beskrivelser af heltene Jørgen Sonne og Klaus Rifbjerg - førstnævnte et suverænt gennemtænkt, analytisk stringent, gennemarbejdet digterportræt og sidstnævnte en nærmest henført indlevelse i et særligt digterisk univers: »Det er en poesi, som har fundet det sproglige instrument, der kan registrere vor fysiologiske sjæl« (122). Man hæfter sig ved gensynet ved, hvor omhyggeligt Torben Brostrøm her etablerer en tætføring imellem formelle og indholdsmæssige dimensioner, som når han om Sonne skriver, at »eksperimentet med materialet, med udtrykket, er (...) uløseligt knyttet til nuanceringen af sjælelige oplevelser« (97), og at poetens kunst 
består i »at sige ting antydelsesvis, at give en uhåndgribelig følelse i dens billedmæssige korrespondenter« (108). Det er, som om det beskrevne litterære objekt tvinger et nyt sprog frem hos litteraturforskeren, når denne må sige, at et billede ikke er en simpel omskrivning, men en sam-sansning, og at en bestemt sekvens ikke er symbolik, men dobbeltoplevelse (109). Sjældent har man set så smuk en bekræftelse på, at nykritikkens fornemste dyd bestod i bestræbelsen på at møde digteren på dennes højeste ambition, netop ved at bortse fra digterens person og give digtet selv lov til at tale ud.

Også i Rifbjerg-portrættet oplever man tilblivelsen af et nyt litteraturkritisk beskrivelsessprog, der så at sige smyger sig om sin genstand, digtet, som dette tages i brug af den enkelte poet. Brostrøm registrerer således det for forfatterskabet altid kendetegnende uophørlige ncerver $i$ ordene og »et meget pågående og ømtåligt, præcist virkende sanseapparat« (114), gerne også lykkeligt forenet med »en højtudviklet kropsbevidsthed i forbindelse med klar intelligens« (124). Som sprogbrugen vidner om, behersker den musikalske kritiker en særlig tætføring af motiver, og man fornemmer ikke sjældent en diskret afsmitning fra objektteksten, en art kamæleonagtig tilpasning til denne - milevidt fra den nuancedøve kategoriserings- og klassificeringsmani hos visse nutidige lyrikforskere.

To specifikke problemer ved Versets Løvemanke påkalder sig kommentarer. Det ene har at gøre med et så besværligt fænomen som lyriske generationer, det andet med Brostrøms måske lovligt smidige forvaltning af nykritikkens begreb om struktur.

Omend bogen, imponerende aktuel, når at forholde sig til hele tre digtsamlinger udsendt samme år som den selv udkommer (Jørgen Gustava Brandts Fragment af $i$ morgen, Jørgen Sonnes Midtvejs og Klaus Rifbjergs Konfrontation), må den i det væsentlige betragtes som en helhedsbeskrivelse af 50'ernes lyrik. Det forpligter Torben Brostrøm til i opfølgningen på de syv enkeltportrætter tillige at strejfe Iljitsch Johannsen, Arne Bøgh Larsen, Karen Stougaard Hansen, Poul Vad, Niels Barfoed og Per Højholt, og desuden styrer han stort set fri af at anvende ordet 'generation'. Og alligevel falder han i, når han kommer til vennen og idolet Klaus Rifbjerg, om hvem det først hedder, at denne tydeligt har markeret »sin samtids- og generationsbevidsthed« (113). Senere i portrættet registreres det, også her vel helt korrekt, at »den generation, Klaus Rifbjerg tilhører« ikke direkte har oplevet »værdiernes sammenbrud «, for »den er vågnet op i ruinerne, hilst velkommen af en smilende homo faber. Anbragt i chassiet med en pedal under foden. Træerne krymper sig, mens pedalen trædes 
ud.« (120). Men da så portrættet skal rundes af, ender Brostrøm nu alligevel med at udråbe Rifbjerg som »den nye generations mest markante navn" (126), og det til trods for, at det i forbindelse med de henholdsvis seks og fem år ældre Ivan Malinovski og Jørgen Sonne netop blev betonet, at disse (i modsætning til idolet) var voksne ved Anden Verdenskrigs afslutning. Mærker man mon her en ansats til det, som den såkaldte »Kolding-skole« (Anne Borup plus til dels hendes venlige mentor AnneMarie Mai) ca. fyrre år senere polemisk stemplede som »den danske modernismekonstruktion« med Brostrøm som chefskurk? I så fald kunne det være betimeligt at understrege, hvor diskret og nuanceret han just $\mathrm{i}$ Versets Løvemanke definerer det så omdiskuterede modernisme-begreb, nemlig som: »en poesiopfattelse, hvis følelsesmæssige grundlag blev lagt omkring 1800, teknisk fik sine karakteristiske træk med symbolismen og endelig med første verdenskrig og teknikkens triumf sit idéindhold." (141). Adskilligt i det 21. århundredes forsøg på litteraturhistorisk revision kunne måske være faldet anderledes ud, hvis afsættet var blevet taget netop her og ikke i den skråsikre, lidt opblæste polemiske opsats i Vindrosen om mådeholdet i dansk lyrik anno 1959.

Heri lød den famøse, ofte citerede og diskuterede passage:

Hvad er da modernisme? En bestræbelse for at trænge ind og ned i det menneskelige, fremmest de egne, som ikke har været bevidst behandlet af ældre digtere. Den sker på baggrund af erfaringer fra moderne psykologi, erkendelse af det ændrede verdensbilledes menneskelige konsekvenser, dvs. at registeret er udvidet og mennesket opfattet som dybere og farligere, i en tid, hvor religiøse, politiske, sociale normer er under forvandling. Digteren erkender, at dette har kunstneriske følger og søger et formsprog, der dækker hans erkendelse. Han kan gøre det ved at lære af andre kunstarter, som måske er kommet længere end hans egen, musik, maleri, skulptur osv. Han må finde en ny struktur, og det er mere end et spørgsmål om rim og versskema, al den stund »form « og »indhold« ikke lader sig behandle hver for sig.

Stedet er her citeret fra antologien Modernismen til debat (redigeret af Anne Borup m.fl., 2005), men kunne også have været sakset fra Brostrøms ovenfor nævnte Ti års lyrik eller fra et hvilket som helst nyere kompendium i det 20. århundredes litteraturhistorie, hvor passagens rolle efterhånden er blevet den at stå som prygelknabe, fordi den lader sig læse, 
som om kritikeren på vegne af en ny generation tager monopol på det moderne og med liden sans for nuancer etablerer et årsag-virknings-forhold mellem psykoanalysens viden og digtekunstens former. Men hvor hans formulereringer i tidsskriftbidraget fra 1959 var bestemt af trang til polemisk positionering, fastholdt han året efter i bogform sin rummelighed og elasticitet.

Afslutningsvis er det værd at notere sig, at Torben Brostrøm i 1960 så langtfra opfører sig som frontkæmper og ideolog. Herom vidner hans mildt sagt fleksible brug af nykritikkens strukturbegreb. I udgangspunktet er det hans hensigt at udskifte dikotomien indhold versus form med flere fleksible begreber, allerhelst holdning og materiale, med struktur som en forbindende kategori, men som hans fremstilling skrider frem, lister der sig uvægerligt mere og mere psyke og sjæl ind i strukturbegrebet. Hos Uffe Harder aflæser han »en psykologisk struktur« (62), hos Robert Corydon iagttager han dog modsat »struktursans« og en forlængelse af den poetiske »strukturfornyelse«, som fandt sted hos Gustaf Munch-Petersen (73); men i forbindelse med Jørgen Sonne kan begrebet igen lades op med ånd og blive til »sindsstruktur« (98). Herfra er der kun ganske kort til i slutkapitlet »Dæmoni og fornuft« at tale om, hvordan ordene »er elementer i en følelsesstruktur, digtet et ordmønster, som ikke direkte fremstiller tanken eller følelsen, men svarer til disses uhåndgribelige form « (149). Her kunne en og anden muligvis efterlyse større terminologisk stringens, men genanmelderen er tilbøjelig til at mene, at Torben Brostrøms endegyldige kapitulation til det genuint menneskelige i kunsten måske er det aspekt af hans første bog, som indgyder størst respekt. 